medRxiv preprint doi: https://doi.org/10.1101/2021.10.14.21264986; this version posted October 16, 2021. The copyright holder for this preprint (which was not certified by peer review) is the author/funder, who has granted medRxiv a license to display the preprint in perpetuity. It is made available under a CC-BY 4.0 International license .

\title{
Metabolic disorders and the risk of head and neck cancer: a protocol for a
}

\section{systematic review and meta-analysis}

Alexander Gormley ${ }^{1,2^{*}}$, Charlotte Richards ${ }^{3 *}$, Francesca Spiga ${ }^{4,5}$, Emily Gray ${ }^{2}$, Joanna Hooper ${ }^{6}$, Barry G Main ${ }^{1,2,4}$, Emma E Vincent ${ }^{4,5,7}$, Rebecca C Richmond ${ }^{4,5}$, Julian PT Higgins ${ }^{4,5}$, Mark Gormley $^{1,2,4,5}$

1-Bristol Dental School, Faculty of Health Sciences, University of Bristol

2 - Bristol Dental Hospital, University Hospitals Bristol and Weston NHS Foundation Trust

3-School of Dentistry, Cardiff University

4 - Population Health Sciences, Bristol Medical School, Faculty of Health Sciences, University of Bristol

5 - MRC Integrative Epidemiology Unit, Population Health Sciences, Bristol Medical School, Faculty of Health Sciences, University of Bristol

6 - Library and information services, University Hospitals Bristol and Weston NHS Foundation

Trust

7-School of Cellular and Molecular Medicine, Faculty of Life Sciences, University of Bristol

* - Joint first authors

Corresponding author- mark.gormley@bristol.ac.uk

Mark Gormley

Bristol Dental School

University of Bristol

Lower Maudlin Street

Bristol

BS1 2LY

NOTE: This preprint reports new research that has not been certified by peer review and should not be used to guide clinical practice. ${ }^{1}$ 


\section{Abstract}

It is made available under a CC-BY 4.0 International license .

\section{Introduction}

Head and neck cancer squamous cell carcinoma (HNSCC) is the $6^{\text {th }}$ most common cancer internationally. Established risk factors include smoking, alcohol and presence of human papillomavirus (HPV). The incidence rate of new disease continues to rise, despite falls in alcohol consumption and a reduction in smoking, the rising rates are unlikely to be solely attributed to HPV status alone. Obesity and its associated conditions such as type 2 diabetes (T2D) are implicated in the risk and progression of a variety of cancers but there is paucity of evidence regarding its role in HNSCC.

\section{Methods and analysis}

A systematic review of cohort studies, reporting a risk of incident head and neck squamous cell carcinoma will be included. A systematic search strategy has been developed, multiple databases will be searched from January 1966, including Cochrane Library, OVID SP versions of Medline and EMBASE. The primary outcome will be incident HNSCC based on exposures of type 2 diabetes, obesity, dyslipidemia and hypertension as defined by the World Health Organisation (WHO). A combined risk effect across studies will be calculated using metaanalysis, although depending on the heterogeneity in study design, exposure and outcome reporting this may not be possible.

\section{Ethics and dissemination}

No ethical approval is required for this systematic review. The review will be published in a revelant peer-review journal and findings will be presented at scientific meetings in both poster and oral presentation form. 
medRxiv preprint doi: https://doi.org/10.1101/2021.10.14.21264986; this version posted October 16,2021 . The copyright holder for this preprint (which was not certified by peer review) is the author/funder, who has granted medRxiv a license to display the preprint in perpetuity. It is made available under a CC-BY 4.0 International license .

This study has been registered with the international prospective register of systematic

reviews (PROSPERO) with study registration number CRD42021250520. This protocol has been developed in accordance with the preferred reporting items for systematic review and metaanalysis protocols (PRISMA-P) guidance statement. 
medRxiv preprint doi: https://doi.org/10.1101/2021.10.14.21264986; this version posted October 16, 2021. The copyright holder for this preprint (which was not certified by peer review) is the author/funder, who has granted medRxiv a license to display the preprint in perpetuity.

\section{Article Summary}

Strengths and limitations of this study

- This systematic review will be the first to comprehensively review the literature and provide a meta-analysis of the effect of metabolic disorders and the risk of incident HNSCC.

- The publication of this protocol provides a clear representation of the methods used in this review for transparency and to prevent future duplication.

- This systematic review will be one of the first to pilot the The ROBINS-E tool (Risk Of Bias In Non-randomised Studies - of Exposures).

- Despite the metabolic disorders being described as separate entities, the authors recognise the potential for disease processes to be related.

- Among cohort studies there is significant variability in terms of length of follow-up for the outcome of interest, HNSCC. 
medRxiv preprint doi: https://doi.org/10.1101/2021.10.14.21264986; this version posted October 16, 2021. The copyright holder for this preprint (which was not certified by peer review) is the author/funder, who has granted medRxiv a license to display the preprint in perpetuity.

\section{Introduction}

It is made available under a CC-BY 4.0 International license .

Head and neck squamous cell carcinoma (HNSCC), which includes cancer of the oral cavity, oropharynx and larynx, is the world's 6th most common cancer, with the highest incidence in males and those over 70 years old. ${ }^{1}$ Established risk factors include smoking, alcohol and the human papillomavirus (HPV), which has mainly been linked to oropharyngeal cancer. ${ }^{2}$ Despite the significant reduction in smoking, ${ }^{3}$ and a fall in alcohol consumption, ${ }^{4}$ in the UK over the previous two decades, incidence rates of head and neck cancers have continued to rise by around a third. ${ }^{1}$ Given this potentially changing aetiology, ${ }^{2}$ further exploration of less well known risk factors is warranted to target prevention and identify patients with early disease. People living with obesity and associated conditions such as type 2 diabetes (T2D), have an increased risk of developing certain cancers (e.g. liver and pancreas), but the epidemiological evidence surrounding HNSCC is not conclusive. ${ }^{5,6}$ Recent studies have demonstrated elevated glucose levels before or at the time of diagnosis, which may play a role in the pathogenesis and progression of cancer. ${ }^{7}$ Carcinogenesis in HNSCC is driven by diverse signalling pathways, however, little is known about the role of metabolism, ${ }^{8}$ despite metabolic reprogramming being a recognised hallmark of cancer. ${ }^{9}$

$\mathrm{T} 2 \mathrm{D}$ is a common condition characterised by insulin resistance and hyperglycaemia, which results in whole body metabolic dysregulation..$^{10}$ In 2015 , the estimated worldwide diabetes prevalence for adults was predicted to rise to 642 million by $2040^{11}$. In addition, public health strategies have not successfully addressed the current 'obesity pandemic' ${ }^{12-16}$ One large pooled analysis demonstrated a weak positive association between T2D and HNSCC (OR 1.09; 95\% confidence interval (95\% Cl): 0.95-1.24), which was stronger amongst those who never smoked cigarettes (OR 1.59; 95\% Cl: 1.22-2.07). ${ }^{6}$ While obesity is a potent risk factor for T2D, the relationship between body mass index (BMI) and HNSCC is not straightforward, with both positive and inverse associations observed. ${ }^{17}$ Another study found that a positive association 
medRxiv preprint doi: https://doi.org/10.1101/2021.10.14.21264986; this version posted October 16, 2021. The copyright holder for this preprint (which was not certified by peer review) is the author/funder, who has granted medRxiv a license to display the preprint in perpetuity.

It is made available under a CC-BY 4.0 International license.

with BMI was only observed in never smokers. ${ }^{18}$ In the largest study to date, waist

circumference (WC) and waist-to-hip ratio (WHR) were positively associated with higher

HNSCC risk, regardless of smoking status. ${ }^{18}$ Metabolic syndrome has been described as a

clustering of disorders including obesity, hypertension, hyperglycaemia and dyslipidemia. A

moderate inverse association has been observed between metabolic syndrome and HNSCC

(OR 0.81; 95\% Cl, 0.78-0.85), but again these results were modified by tobacco use. ${ }^{19}$

Treatment for these conditions using medications such as statins, ${ }^{20}$ or metformin, ${ }^{21}$ may also

reduce the risk of developing HNSCC. Given the growing pandemic of metabolic disorders,

understanding how these alterations affect the risk of carcinogenesis may identify those who

are high risk. This could drive targeted prevention, earlier detection and perhaps the

identification or repurposing of drug targets for treatment in HNSCC. ${ }^{22}$

\section{Rationale}

The complex metabolic changes associated with T2D, obesity, dyslipidemia and hypertension may alter the risk of certain cancers, but the evidence for head and neck cancer is inconclusive.

This study aims to identify, collate and synthesise all relevant studies including adult

participants, to determine whether the risk of developing incident HNSCC is influenced by T2D, obesity, dyslipidemia and hypertension, using relevant effect measures (e.g., odds or risk ratios). Where available, we will further stratify by subsite (i.e., oral cavity, oropharynx and larynx), as well as by HPV status.

\section{Methods}

Research Question

'Do metabolic disorders affect the risk of developing head and neck cancer?' 
medRxiv preprint doi: https://doi.org/10.1101/2021.10.14.21264986; this version posted October 16, 2021. The copyright holder for this preprint (which was not certified by peer review) is the author/funder, who has granted medRxiv a license to display the preprint in perpetuity.

It is made available under a CC-BY 4.0 International license .

Randomised controlled trials are informative for assessing causal effects, however due to the

nature of the exposures in this study, inclusion of this design are not feasible. Therefore, we

will focus on observational (e.g., cohort studies) reporting the risk of metabolic disorders on

incident head and neck squamous cell carcinoma.

\section{Eligibility criteria}

Population- participants over 18 years old, of either sex, from any ethnic background.

Exposures- 1) type 2 diabetes, 2) obesity, 3) dyslipidemia and 4) hypertension. These will be collectively described as 'metabolic disorders.

Comparison- participants who have not been diagnosed with the aforementioned metabolic disorders.

Outcome- incident head and neck squamous cell carcinoma.

Table 1. Study selection criteria

\begin{tabular}{|c|c|}
\hline Inclusion criteria & Exclusion criteria \\
\hline $\begin{array}{l}\text { - All studies published from January } 1966 \text { in the } \\
\text { English language. } \\
\text { - Participants humans }>18 \text { years old, of either sex } \\
\text { and any ethnic background. } \\
\text { - Observational (e.g., cohort studies) reporting the } \\
\text { risk of incident head and neck squamous cell } \\
\text { carcinoma. } \\
\text { - Studies must report an odds ratio (OR) or risk } \\
\text { ratio (RR), or data which will allow these to be } \\
\text { calculated. }\end{array}$ & $\begin{array}{l}\text { - The study is not based on incident head and } \\
\text { neck squamous cell carcinoma, or contains only } \\
\text { prevalent data, meaning a temporal relationship } \\
\text { cannot be inferred. } \\
\text { - Studies focused on cancer survival or } \\
\text { progression. } \\
\text { - Study designs such as case reports or case } \\
\text { series. In addition, cross-sectional, case-control } \\
\text { and narrative review studies will be excluded } \\
\text { due to the inability to infer a temporal } \\
\text { relationship. }\end{array}$ \\
\hline $\begin{array}{l}\text { - Exposures: Type } 2 \text { diabetes, obesity, dyslipidemia } \\
\text { and hypertension with definitions as described in } \\
\text { the study protocol. } \\
\text { - An outcome of head and neck cancer diagnosis } \\
\text { which may be human papilloma virus (HPV) } \\
\text { positive or negative. High risk types HPV16, 18, } \\
\text { 31, and } 33 \text { only will be included. }\end{array}$ & $\begin{array}{l}\text { - Human studies only, no in vivo animal or in vitro } \\
\text { cell line studies. } \\
\text { - Studies of head and neck epithelial dysplasia, } \\
\text { potentially malignant disease or carcinoma in } \\
\text { situ. } \\
\text { - Squamous cell carcinoma of other sites e.g., } \\
\text { nasopharynx, salivary gland, oesophagus, skin or } \\
\text { lung due to differing aetiology and risk factors } \\
\text { e.g., Epstein Barr Virus. }\end{array}$ \\
\hline
\end{tabular}


medRxiv preprint doi: https://doi.org/10.1101/2021.10.14.21264986; this version posted October 16, 2021. The copyright holder for this preprint (which was not certified by peer review) is the author/funder, who has granted medRxiv a license to display the preprint in perpetuity.

It is made available under a CC-BY 4.0 International license .

The study will report in line with the Preferred Reporting Items for Systematic Reviews and

Meta-Analyses (PRISMA) statement and has been pre-registered on International Prospective

Register of Systematic Reviews (PROSPERO) in 2021 (CRD42021250520).

Search strategy

A systematic search strategy (Supplementary Table 1) has been formulated by clinicians, scientific researchers and a specialist librarian for Surgery, Head \& Neck and Medicine. Medical Subject Headings (MeSH) and keywords will be iteratively combined with the Boolean operators AND, OR and NOT. Multiple databases will be searched from January 1966, including Cochrane Library, OVID SP versions of Medline and EMBASE. Pre-print servers including medRxiv and bioRxiv will also be searched. In addition, the following electronic bibliographic databases will be searched: EThOS, Google Scholar, Open Grey and ClinicalTrials.gov, to identify articles from the grey literature and conference proceedings. References extracted from the full-length articles will be reviewed to identify other publications of interest. Duplicate articles will be removed using Covidence $\bigodot^{23}$.

\section{Data management}

The results from searches will be imported into Covidence@ software, to improve reference management and workflow. This will also populate a PRISMA flow diagram. ${ }^{24}$

\section{Data screening and extraction}

All titles and abstracts will be screened by two authors A.G. and C.R., with conflicts resolved by A.G., C.R. and M.G. Screening records and decisions will be kept in Covidence@. Data will be extracted from titles that meet the inclusion criteria (Table 1). The data extraction form

(Supplementary Table 2) will be piloted using 5 included titles with A.G., C.R. and M.G. independently completing data extraction. If amendments are necessary they will be 
medRxiv preprint doi: https://doi.org/10.1101/2021.10.14.21264986; this version posted October 16, 2021. The copyright holder for this preprint (which was not certified by peer review) is the author/funder, who has granted medRxiv a license to display the preprint in perpetuity.

It is made available under a CC-BY 4.0 International license .

performed at this point, with consensus approval required prior to final use of the form.

Subsequent to this, C.R. and M.G. will double data extract indepdently for each title, any

disagreements will be discussed between A.G., C.R. and M.G. with consensus approval

required.

Disease definitions:

1) The World Health Organization (WHO) defines T2D as a chronic disease that occurs when the body cannot effectively use the insulin it produces and is largely the result of excess body weight and physical inactivity. A diagnosis of T2D is defined as symptoms such as polyuria or polydipsia, plus: $:^{25,26}$

- a random blood plasma glucose concentration $\geq 11.1 \mathrm{mmol} / \mathrm{l}$ or;

- a fasting plasma glucose concentration $\geq 7.0 \mathrm{mmol} / \mathrm{l}$ (whole blood $\geq 6.1 \mathrm{mmol} / \mathrm{l}$ ) or;

- two hour plasma glucose concentration $\geq 11.1 \mathrm{mmol} / \mathrm{l}$ two hours after $75 \mathrm{~g}$ anhydrous glucose in an oral glucose tolerance test (OGTT) or;

- glycated haemoglobin (HbA1c) $6.5 \%$ or more ( $48 \mathrm{mmol} / \mathrm{mol}$ and above)

2) The World Health Organization (WHO) defines obesity as having: a body mass index (BMI) of 30 or above. ${ }^{27}$

3) Dyslipidemia is classified as serum total cholesterol (TC), low density lipoprotein cholesterol (LDL-C), triglycerides, apolipoprotein B, or lipoprotein(a) concentrations above the $90^{\text {th }}$ percentile, or high density lipoprotein cholesterol (HDL-C) or apolipoprotein concentrations below the 10th percentile for the general population. ${ }^{28}$

4) The World Health Organization (WHO) defines hypertension as: ${ }^{29}$ 
medRxiv preprint doi: https://doi.org/10.1101/2021.10.14.21264986; this version posted October 16, 2021. The copyright holder for this preprint (which was not certified by peer review) is the author/funder, who has granted medRxiv a license to display the preprint in perpetuity.

It is made available under a CC-BY 4.0 International license .

- a systolic blood pressure reading of $\geq 140 \mathrm{mmHg}$ when recorded on two different days; and/or

- a diastolic blood pressure readings on both days of $\geq 90 \mathrm{mmHg}$.

A diagnosis of incident head and neck squamous cell carcinoma should be confirmed by histology by a trained pathologist. Cancer diagnosis and confirmation may be reported using the International Classification of Diseases (ICD) codes. $^{30}$ Cancer cases for the disease of interest have the following ICD codes: oral cavity (CO2.0-C02.9, C03.0-C03.9, C04.0-C04.9, C05.0-C06.9) oropharynx (C01.9, C02.4, C09.0-C10.9), hypopharynx (C13.0-C13.9), overlapping (C14 and combination of other sites) and 25 cases with unknown ICD code (other). With respect to HPV diagnosis, only high risk subtypes HPV16, 18, 31, and 33 will be included. These are should be detected using HPV-DNA via polymerase chain reaction (PCR) and/or in situ hybridization (ISH) examination, usually used in combination with immunohistochemistry for p16.

\section{Data analysis and synthesis}

The analysis and synthesis process will be performed in two phases. The first phase consists of estimating the effect of each metabolic disorder (T2D, obesity, dyslipidemia and hypertension) on incident HNSCC separately for each included study. Effects should be reported as odds (OR) or risk ratios (RR), with $95 \%$ confidence intervals or in a format that will enable us to calculate these.

The second phase will focus on estimating the combined effect across studies using metaanalysis, using metafor software in $\mathrm{R}$ (R Core Team, version 4.0.3). ${ }^{31}$ The analysis will yield information about the heterogeneity of effects across studies, using Cochran's Q test and Higgins' $I^{2}$ statistic. Due to the heterogeneity in study design, exposure definition and outcome reporting in the included studies, meta-analysis may not be reasonable. 


\section{Subgroup analyses}

Where possible, we will stratify by oral, oropharyngeal and laryngeal subsite and by HPV-status as post-hoc analyses, to determine if effects seen are specific to a particular anatomical region or associated with specific tumour types.

\section{Risk of bias in studies}

Two authors will independently extract the relevant risk factor information during data extraction using a preliminary version of the Risk of Bias in Non-randomised Studies - of Exposures (ROBINS-E) tool (https://www.bristol.ac.uk/population-healthsciences/centres/cresyda/barr/riskofbias/robins-e/). ${ }^{32}$ The ROBINS-E tool aims to assess the result of interest from an observational study for risk of bias, where that study is designed to assess the effect of exposure on outcome. ${ }^{32}$ Disagreements will be recorded and discussed with a third author for resolution. This assessment will be used in evaluating the strength of evidence from the included studies.

\section{Amendments}

Any amendments to the initial protocol will be included in an update to the PROSPERO record, including information on amendment type, reasoning and a timestamp. Deviation from this protocol will be described in the full systematic review paper. 
medRxiv preprint doi: https://doi.org/10.1101/2021.10.14.21264986; this version posted October 16, 2021. The copyright holder for this preprint (which was not certified by peer review) is the author/funder, who has granted medRxiv a license to display the preprint in perpetuity.

\section{Dissemination}

It is made available under a CC-BY 4.0 International license.

This systematic review will be published in a relevant peer-reviewed journal and findings from this work may be presented at scientific meetings (both poster and oral presentations).

\section{Ethical approval}

No ethical approval is required for the conducting of this systematic review.

\section{Acknowledgements}

None to declare. 
medRxiv preprint doi: https://doi.org/10.1101/2021.10.14.21264986; this version posted October 16, 2021. The copyright holder for this preprint (which was not certified by peer review) is the author/funder, who has granted medRxiv a license to display the preprint in perpetuity.

\section{References}

It is made available under a CC-BY 4.0 International license.

1. Cancer Research UK (CRUK). Head and neck cancer statistics 2019 [cited 2019 11/04/2019]. Available from: https://www.cancerresearchuk.org/health-professional/cancer-statistics/statistics-bycancer-type/head-and-neck-cancers\#heading-Two accessed 13/09/2021 2019.

2. Thomas SJ, Penfold CM, Waylen A, et al. The changing aetiology of head and neck squamous cell cancer: A tale of three cancers? Clin Otolaryngol 2018;43(4):999-1003. doi: 10.1111/coa.13144

3. Office for National Statistics. Data for 1974 onwards: Office for National Statistics. Adult Smoking habits in Great Britain. 2020 [Available from:

https://www.ons.gov.uk/peoplepopulationandcommunity/healthandsocialcare/drugusealcohol andsmoking/datasets/adultsmokinghabitsingreatbritain. accessed 01/03/2021 2020.

4. Office for National Statistics. Adult drinking habits in Great Britain 2017 [Available from: https://www.ons.gov.uk/peoplepopulationandcommunity/healthandsocialcare/drugusealcohol andsmoking/datasets/adultdrinkinghabits accessed 01/03/2021 2021.

5. Wotton CJ, Yeates DG, Goldacre MJ. Cancer in patients admitted to hospital with diabetes mellitus aged 30 years and over: record linkage studies. Diabetologia 2011;54(3):527-34. doi: 10.1007/s00125-010-1987-2 [published Online First: 2010/12/01]

6. Stott-Miller M, Chen C, Chuang SC, et al. History of diabetes and risk of head and neck cancer: a pooled analysis from the international head and neck cancer epidemiology consortium. Cancer Epidemiol Biomarkers Prev 2012;21(2):294-304. doi: 10.1158/1055-9965.EPI-11-0590 [published Online First: 2011/12/07]

7. Vilaseca I, Fuster G, Avilés-Jurado FX. The impact of diabetes in head and neck cancer. Curr Opin Otolaryngol Head Neck Surg 2020;28(2):107-11. doi: 10.1097/moo.0000000000000606 [published Online First: 2020/02/06]

8. Rego DF, Elias ST, Amato AA, et al. Anti-tumor effects of metformin on head and neck carcinoma cell lines: A systematic review. Oncol Lett 2017;13(2):554-66. doi: 10.3892/ol.2016.5526 [published Online First: 2017/03/31]

9. Hanahan D, Weinberg RA. Hallmarks of Cancer: The Next Generation. Cell 2011;144(5):646-74. doi: 10.1016/j.cell.2011.02.013

10. Koivula RW, Heggie A, Barnett A, et al. Discovery of biomarkers for glycaemic deterioration before and after the onset of type 2 diabetes: rationale and design of the epidemiological studies within the IMI DIRECT Consortium. Diabetologia 2014;57(6):1132-42. doi: 10.1007/s00125-0143216-x [published Online First: 2014/04/04]

11. Ogurtsova K, da Rocha Fernandes JD, Huang Y, et al. IDF Diabetes Atlas: Global estimates for the prevalence of diabetes for 2015 and 2040. Diabetes Res Clin Pract 2017;128:40-50. doi: 10.1016/j. diabres.2017.03.024 [published Online First: 2017/04/25]

12. Wolf AM, Colditz GA. Current estimates of the economic cost of obesity in the United States. Obes Res 1998;6(2):97-106. doi: DOI 10.1002/j.1550-8528.1998.tb00322.x

13. Dombrowski SU, Knittle K, Avenell A, et al. Long term maintenance of weight loss with non-surgical interventions in obese adults: systematic review and meta-analyses of randomised controlled trials. Bmj-Brit Med J 2014;348 doi: ARTN g2646

10.1136/bmj.g2646 
medRxiv preprint doi: https://doi.org/10.1101/2021.10.14.21264986; this version posted October 16, 2021. The copyright holder for this preprint (which was not certified by peer review) is the author/funder, who has granted medRxiv a license to display the preprint in perpetuity.

It is made available under a CC-BY 4.0 International license .

14. Gray L, Cooper N, Dunkley A, et al. A systematic review and mixed treatment comparison of pharmacological interventions for the treatment of obesity. Obes Rev 2012;13(6):483-98. doi: 10.1111/j.1467-789X.2011.00981.x

15. Yanovski SZ, Yanovski JA. Long-term Drug Treatment for Obesity A Systematic and Clinical Review. Jama-J Am Med Assoc 2014;311(1):74-86. doi: 10.1001/jama.2013.281361

16. Corbin L, Timpson NJ. Body Mass Index: Has Epidemiology Started to Break Down Causal Contributions to Health and Disease? Obesity 2016;24(8):1630-38. doi: 10.1002/oby. 21554

17. Maasland DH, van den Brandt PA, Kremer B, et al. Body mass index and risk of subtypes of headneck cancer: the Netherlands Cohort Study. Sci Rep 2015;5:17744. doi: 10.1038/srep17744 [published Online First: 2015/12/05]

18. Gaudet MM, Kitahara CM, Newton CC, et al. Anthropometry and head and neck cancer:a pooled analysis of cohort data. Int J Epidemiol 2015;44(2):673-81. doi: 10.1093/ije/dyv059 [published Online First: 2015/06/08]

19. Stott-Miller M, Chen C, Schwartz SM. Type II diabetes and metabolic syndrome in relation to head and neck squamous cell carcinoma risk: a SEER-Medicare database study. Cancer Epidemiol 2013;37(4):428-33. doi: 10.1016/j.canep.2013.03.006 [published Online First: 2013/04/09]

20. Kao LT, Hung SH, Kao PF, et al. Inverse association between statin use and head and neck cancer: Population-based case-control study in Han population. Head Neck-J Sci Spec 2019;41(5):119398. doi: $10.1002 /$ hed. 25501

21. Yen YC, Lin C, Lin SW, et al. Effect of metformin on the incidence of head and neck cancer in diabetics. Head Neck 2015;37(9):1268-73. doi: 10.1002/hed.23743 [published Online First: 2014/05/08]

22. Ramteke P, Deb A, Shepal V, et al. Hyperglycemia Associated Metabolic and Molecular Alterations in Cancer Risk, Progression, Treatment, and Mortality. Cancers (Basel) 2019;11(9) doi: 10.3390/cancers11091402 [published Online First: 2019/09/25]

23. Covidence. Covidence - Better systematic review management 2021 [Available from: https://www.covidence.org/ accessed 13/09/2021 2021.

24. Liberati A, Altman DG, Tetzlaff J, et al. The PRISMA statement for reporting systematic reviews and meta-analyses of studies that evaluate healthcare interventions: explanation and elaboration. BMJ 2009;339:b2700. doi: 10.1136/bmj.b2700

25. World Health Organization. Definition and Diagnosis of Diabetes Mellitus and Intermediate Hyperglycaemia 2006 [Available from: https://www. diabetes.org.uk/resources-s3/201709/Definition and diagnosis1111.pdf accessed 01/03/2021 2021.

26. World Health Organization. Use of Glycated Haemoglobin (HbA1c) in the Diagnosis of Diabetes Mellitus 2011 [Available from: https://www. diabetes.org.uk/resources-s3/201709/Definition and diagnosis1111.pdf accessed 01/03/2021 2021.

27. World Health Organization. Obesity and overweight 2021 [Available from: https://www.who.int/news-room/fact-sheets/detail/obesity-and-overweight accessed 01/03/2021 2021.

28. British Medical Journal. Hypercholesterolemia 2019 [Available from: https://bestpractice.bmi.com/topics/en-us/170 accessed 28.03.2021 2021.

29. Organization WH. Hypertension 2021 [Available from: https://www.who.int/news-room/factsheets/detail/hypertension accessed 13/09/2021 2021. 
medRxiv preprint doi: https://doi.org/10.1101/2021.10.14.21264986; this version posted October 16, 2021. The copyright holder for this preprint (which was not certified by peer review) is the author/funder, who has granted medRxiv a license to display the preprint in perpetuity. It is made available under a CC-BY 4.0 International license.

30. Organization WH. International Statistical Classification of Diseases and Related Health Problems (ICD) 2021 [accessed 13/09/2021 2021.

31. Viechtbauer W. metafor: Meta-Analysis Package for R 2021 [Available from: https://cran.rproject.org/web/packages/metafor/index.html accessed October 2021 October 2021.

32. Bristol Uo. The ROBINS-E tool (Risk Of Bias In Non-randomized Studies - of Exposures) 2021 [Available from: http://www.bristol.ac.uk/population-healthsciences/centres/cresyda/barr/riskofbias/robins-e/ accessed 13/09/2021 2021. 
medRxiv preprint doi: https://doi.org/10.1101/2021.10.14.21264986; this version posted October 16, 2021. The copyright holder for this preprint (which was not certified by peer review) is the author/funder, who has granted medRxiv a license to display the preprint in perpetuity.

\section{Authors' contributions}

$A G$ and $C R$ jointly contributed to the development of the protocol and the drafting, writing and editing of this manuscript. FS contributed to the development of this study and editing of the manuscript. JH contributed to the development of the search strategy. BM, EG, EV, RR and JPTH contributed to the development of this study. MG was responsible for conceptualising this study, drafting and editing this manuscript. All authors contributed to the development of the search strategy. All authors have approved and contributed to the final written manuscript.

\section{Funding statement}

A.G. is a National Institute for Health Research (NIHR) academic clinical fellow. F.S. was supported by a Cancer Research UK (C18281/A29019) programme grant (the Integrative Cancer Epidemiology Programme). E.E.V is supported by Diabetes UK (17/0005587). E.E.V is also supported by the World Cancer Research Fund (WCRF UK), as part of the World Cancer Research Fund International grant programme (IIG_2019_2009). R.C.R. is a de Pass VC research fellow at the University of Bristol. J.P.T.H supported by the NIHR Biomedical Research Centre at University Hospitals Bristol and Weston NHS Foundation Trust and the University of Bristol, the NIHR Applied Research Collaboration West at University Hospitals Bristol and Weston NHS Foundation Trust and is a National Institute for Health Research (NIHR) Senior Investigator. M.G. is currently supported by a Wellcome Trust GW4-Clinical Academic Training PhD Fellowship. This research was funded in part, by the Wellcome Trust [Grant number 220530/Z/20/Z]. For the purpose of Open Access, the author has applied a CC BY public copyright licence to any Author Accepted Manuscript version arising from this submission. The views expressed in this publication are those of the author(s) and not necessarily those of Wellcome, NIHR, the NHS or Department of Health. 
medRxiv preprint doi: https://doi.org/10.1101/2021.10.14.21264986; this version posted October 16, 2021. The copyright holder for this preprint (which was not certified by peer review) is the author/funder, who has granted medRxiv a license to display the preprint in perpetuity.

It is made available under a CC-BY 4.0 International license.

\section{Competing interests statement}

None declared

Word Count: 1,755 (excluding abstract) 
medRxiv preprint doi: https://doi.org/10.1101/2021.10.14.21264986; this version posted October 16, 2021. The copyright holder for this preprint (which was not certified by peer review) is the author/funder, who has granted medRxiv a license to display the preprint in perpetuity.

\section{Supplementary Table 1. Search strategy}

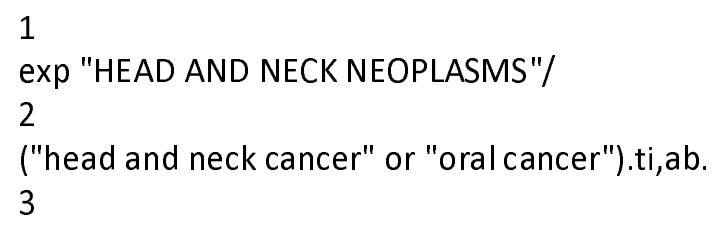
density lipoprotein" or "apolipoprotein" or cholesterol or LDL or triglycerides or statin* or ezetimibe or "HMG-COA" or "reductase inhibitor*" or "HMGCR" or "hydroxymethylglutaryl coa reductases" or "NPC1L1" or "PCSK9" or "CETP" or "LDLR" or atorvastatin or fluvastatin or lovastatin or pitavastatin or pravastatin or rosuvastatin or simvastatin or (lipid* adj2 (metaboli* or medicat* or drug* or lower* or reduc* or decreas*))l.ti,ab.

7

5 or 6

8

exp DIABETES MELLITUS/

9

(Diabet* or insulin or "insulin resistance" or hyperglycaemia or hypoglycaemia or hyperglycemia or hypoglycemia or hypertension or metformin or glucagon or "hypoglycaemic agent*" or HbA1 or HbA1C or (glucose adj2 (impair* or tolerance or intolerance)) or IGT or glycogenolysis or gluconeogenesis or GDF?15 or gliflozins or SGLT2 or sulphonylurea* or meglitinide* or thiazolidinediones or "DPP-4 inhibitor*" or "GLP-1 receptor agonist*").ti,ab.

10

8 or 9

11

exp METABOLIC SYNDROME/

12

(metabolic syndrome or "dyresgulated metaboli*" or obesity or obes* or "abdominal obes*" or (fat or fatty or fats) or "body weight" or adipos* or (weight adj2 gain*) or overeat* or bariatric or (over adj2 eat) or "body mass index*" or BMI).ti,ab.

13

11 or 12

14

7 or 10 or 13

15

4 and 14

16

exp RISK/

17

(risk* or inciden* or prevalen*).ti,ab.

18

16 or 17

19

15 and 18 
medRxiv preprint doi: https://doi.org/10.1101/2021.10.14.21264986; this version posted October 16, 2021. The copyright holder for this preprint (which was not certified by peer review) is the author/funder, who has granted medRxiv a license to display the preprint in perpetuity.

Supplementary Table 2. Data extraction table. Note separate table for each exposure (Obesity,

Dyslipidaemia, Hypertension, Type 2 diabetes). 
medRxiv preprint doi: https://doi.org/10.1101/2021.10.14.21264986; this version posted October 16, 2021. The copyright holder for this preprint (which was not certified by peer review) is the author/funder, who has granted medRxiv a license to display the preprint in perpetuity.

\title{
Reporting checklist for protocol of a systematic review and meta analysis.
}

\author{
Instructions to authors
}

Complete this checklist by entering the page numbers from your manuscript where readers will find each of the items listed below.

Your article may not currently address all the items on the checklist. Please modify your text to include the missing information. If you are certain that an item does not apply, please write "n/a" and provide a short explanation.

Upload your completed checklist as an extra file when you submit to a journal.

In your methods section, say that you used the PRISMA-Preporting guidelines, and cite them as:

Moher D, Shamseer L, Clarke M, Ghersi D, Liberati A, Petticrew M, Shekelle P, Stewart LA. Preferred Reporting Items for Systematic Review and Meta-Analysis Protocols (PRISMA-P) 2015 statement. Syst Rev. 2015;4(1):1.

Title

Identification

Update

Registration

\#2 If registered, provide the name of the registry (such as PROSPERO) and registration number

\section{Authors}

Contact

Contribution

Describe contributions of protocol authors and identify the

\section{Amendments}

\#4 If the protocol represents an amendment of a previously completed or published protocol, identify as such and list changes; otherwise, state plan for documenting important protocol amendments

\section{Support}


medRxiv preprint doi: https://doi.org/10.1101/2021.10.14.21264986; this version posted October 16, 2021. The copyright holder for this preprint (which was not certified by peer review) is the author/funder, who has granted medRxiv a license to display the preprint in perpetuity.

It is made available under a CC-BY 4.0 International license .

Sources

Sponsor

Role of sponsor or funder

\section{Introduction}

Rationale

Objectives

\section{Methods}

Eligibility criteria

Information

sources

Search strategy

Study records -

data management

Study records -

selection process

Study records -

data collection

process

Data items

Outcomes and

prioritization

Risk of bias in individual studies \#5a Indicate sources of financial or other support for the review

\#5b Provide name for the review funder and / or sponsor

$\# 5 \mathrm{c}$

Describe roles of funder(s), sponsor(s), and / or institution(s), if any, in developing the protocol

\#6 Describe the rationale for the review in the context of what is already known

\#7 Provide an explicit statement of the question(s) the review will address with reference to participants, interventions, comparators, and outcomes (PICO)

\#8 Specify the study characteristics (such as PICO, study design, setting, time frame) and report characteristics (such as years considered, language, publication status) to be used as criteria for eligibility for the review

\#9 Describe all intended information sources (such as electronic databases, contact with study authors, trial registers or other grey literature sources) with planned dates of coverage

\#10 Present draft of search strategy to be used for at least one electronic database, including planned limits, such that it could be repeated

\#11a Describe the mechanism(s) that will be used to manage records and data throughout the review

\#11b State the process that will be used for selecting studies (such as two independent reviewers) through each phase of the review (that is, screening, eligibility and inclusion in metaanalysis)

\#11c Describe planned method of extracting data from reports (such as piloting forms, done independently, in duplicate), any processes for obtaining and confirming data from investigators

\#12 List and define all variables for which data will be sought (such as PICO items, funding sources), any pre-planned data assumptions and simplifications

\#13 List and define all outcomes for which data will be sought, including prioritization of main and additional outcomes, with rationale

\#14 Describe anticipated methods for assessing risk of bias of individual studies, including whether this will be done at the outcome or study level, or both; state how this information will be used in data synthesis 
medRxiv preprint doi: https://doi.org/10.1101/2021.10.14.21264986; this version posted October 16, 2021. The copyright holder for this preprint (which was not certified by peer review) is the author/funder, who has granted medRxiv a license to display the preprint in perpetuity.

It is made available under a CC-BY 4.0 International license.

Data synthesis \#15a Describe criteria under which study data will be quantitatively

10-11

synthesised

Data synthesis \#15b If data are appropriate for quantitative synthesis, describe planned summary measures, methods of handling data and methods of combining data from studies, including any planned exploration of consistency (such as I2, Kendall's T)

Data synthesis

\#15c Describe any proposed additional analyses (such as sensitivity or subgroup analyses, meta-regression)

Data synthesis

\#15d If quantitative synthesis is not appropriate, describe the type of $\mathrm{N} / \mathrm{A}$

Meta-bias(es)

\#16 Specify any planned assessment of meta-bias(es) (such as publication bias across studies, selective reporting within studies)

Confidence in

\#17 Describe how the strength of the body of evidence will be

cumulative assessed (such as GRADE)

evidence

The PRISMA-P elaboration and explanation paper is distributed under the terms of the Creative Commons Attribution License CC-BY. This checklist was completed on 13. September 2021 using https://www.goodreports.org/, a tool made by the EQUATOR Network in collaboration with Penelope.ai 